\title{
Protein Reagent Modification of Cholera Toxin: Characterization of Effects on Antigenic, Receptor-binding and Toxic Properties
}

\author{
By I. LÖNNROTH AND J. HOLMGREN \\ Institute of Medical Microbiology, University of Göteborg and \\ the National Bacteriological Laboratory, Stockholm, Sweden
}

(Received 6 March 1975; revised 12 June 1975)

\begin{abstract}
SUMMARY
The effects of protein modification procedures on the biologically most important properties of cholera toxin, i.e. the toxic activity, the $G_{M 1}$ receptor-binding capacity and the antigenic (antibody-fixing) properties, have been studied quantitatively using microgram amounts or less of toxin protein.

Most of the 24 group-specific reagents used had either no inhibitory effect on the toxic or the combination of $\mathrm{G}_{\mathrm{m} 1}$-binding and antibody-fixing properties of cholera toxin, or they had a concomitant inhibitory effect on these activities. Separate testing of $\mathrm{G}_{\mathrm{M} 1^{-}}$and antibody-binding revealed a close, but not absolute, structural association between these properties. Amino group reactive substances were particularly effective in decreasing the $\mathrm{G}_{\mathrm{M} 1}$-binding activity, while leucine aminopeptidase had no effect. This suggests that lysine residues may be involved in binding toxin to the acidic $\mathrm{G}_{\mathrm{M} 1}$ receptor.

Sodium dodecylsulphate and mercaptoethanol, which caused dissociation of the subunits of cholera toxin as indicated by polyacrylamide gel electrophoresis, abolished toxicity without inhibiting the concomitant $\mathrm{G}_{\mathrm{M1}}$ - and antibody-binding properties of the toxin. Similar differential effects were also obtained with three reagents which did not seem to change the aggregation state of the toxin. These substances all had specificity for arginine, suggesting that arginyl residues of the toxin molecule may be involved in a 'toxic site' distinct from the receptor-binding site(s). A selective effect on the toxic site was also found by treating the toxin with carboxypeptidase or trypsin in the presence of urea; in the absence of urea no enzymic effect on any toxin property was noted.
\end{abstract}

\section{INTRODUCTION}

Recent research has shed much light on the biochemical aspects of cholera. The choleragenic agent has been identified as an antigenic, neutral protein exotoxin with a molecular weight of 84000 , and has been obtained in a pure form (Finkelstein \& Lo Spalluto, I970; Lo Spalluto \& Finkelstein, 1972). The activity of the toxin seems to be due to its ability to activate adenylate cyclase in the small bowel mucosa, leading to a dramatic increase of intestinal electrolyte and fluid secretion which results in profuse diarrhoea (Field et al. 1972; Schafer et al. 1970; Sharp \& Hynie, 1970; Pierce, Greenough \& Carpenter, 1971). When added to other tissues the toxin causes various effects all of which, however, appear to be secondary to enhanced formation of cyclic 3',5'-adenosine monophosphate in the responding cells (Pierce et al. 1971). The local development of increased vascular permeability in the skin of rabbits following intradermal injection of cholera toxin is the basis for a widely employed assay of toxicity (Craig, I975).

Rapid tight binding to the outer membrane of target cells precedes the biological action 
of the toxin (Cuatrecasas, I973a; Holmgren, Lindholm \& Lönnroth, 1974) and it is probable that the membrane binding site is the ganglioside $\mathrm{G}_{M 1}$ (monosialosyl- $N$-tetra-glycosylceramide) (Holmgren, Lönnroth \& Svennerholm, 1973; Cuatrecasas, 1973 $b$; King \& van Heyningen, 1973). In a functional characterization of the toxin it is important to find out how its structure determines both receptor-binding and toxic properties. The relationship between structure and antigenicity is also of obvious importance in protective immunity and immunoprophylaxis. One heavy $(\mathrm{H})$ and about seven light $(\mathrm{L})$ subunits linked non-covalently make up a toxin molecule (Lönnroth \& Holmgren, I973; Cuatrecasas, Parikh \& Hollenberg, 1973; van Heyningen, 1974; Holmgren \& Lönnroth, 1975). The L-type of subunit is responsible for the cell-binding and $\mathrm{G}_{\mathrm{M}_{1}}$-ganglioside-binding ability of the toxin and also for most of its antigenicity (Holmgren et al. 1974; Holmgren \& Lönnroth, 1975). The $\mathrm{H}$ subunit, which is also antigenic, is necessary for the toxicity and probably represents the portion of the toxin which, directly or via an intermediate reaction, activates cellular adenylate cyclase (Lönnroth \& Holmgren, I973; Cuatrecasas et al. 1973; Holmgren et al. 1974). Other authors have used a different subunit nomenclature: Cuatrecasas et al. (1973) name the aggregated $L$ subunits of cholera toxin ' $A$ ', the dissociated $L$ subunits ' $C$ ', and the $H$ subunit ' $B$ '; van Heyningen (I974) calls the $L$ and $H$ subunits ' $B$ ' and ' $A$ ', respectively.

We have applied residue-specific protein modification procedures, commonly used in enzymology, to prepare numerous derivatives of the toxin. Methods have been devised which permit the quantitative study of these modifications on the toxic, receptor-binding and antigenic properties, using only micrograms or less of the cholera toxin derivatives. A preliminary report has been published (Lönnroth \& Holmgren, 1974).

\section{METHODS}

Cholera toxin. Highly purified cholera toxin, prepared from Vibrio cholerae strain 569B by R. A. Finkelstein, Dallas, Texas (Finkelstein \& Lo Spalluto, 1970), was obtained from the National Institutes of Allergy and Infectious Diseases, Bethesda, Maryland, U.S.A. The freeze-dried material was dissolved in sterile tris-EDTA buffer, $\mathrm{pH} 7.5(0.05 \mathrm{M}$-tris, $0.00 \mathrm{I} \mathrm{M}-\mathrm{Na}_{2}$-EDTA, $0.003 \mathrm{M}-\mathrm{NaN}_{3}, 0.2 \mathrm{M}-\mathrm{NaCl}$ ) to give a solution containing $5 \mathrm{mg} / \mathrm{ml}$ which was dispensed in small volumes and stored at $-70^{\circ} \mathrm{C}$ until used.

${ }^{125}$ I-labelled cholera toxin. Cholera toxin was labelled with ${ }^{125} \mathrm{I}$ by the chloramine $\mathrm{T}$ method (Hunter \& Greenwood, 1962). Carrier-free $\mathrm{Na}^{125} \mathrm{I}$ (specific activity $>$ I4 $\mathrm{mCi} / \mu \mathrm{g}$ ) was purchased from the Radiochemical Centre, Amersham, Buckinghamshire. To Io $\mu \mathrm{l}$ of cholera toxin $\left(5 \mathrm{mg} / \mathrm{ml}\right.$ in tris-EDTA buffer) was added $5 \mu \mathrm{l} \mathrm{Na}{ }^{125} \mathrm{I}(=0.5 \mathrm{mCi})$ and $2.5 \mu \mathrm{l}$ chloramine $\mathrm{T}$ ( $\mathrm{I} 0 \mathrm{mg} / \mathrm{ml}$ in distilled water; Merck, Darmstadt, Germany). After I min at $23{ }^{\circ} \mathrm{C}$ the reaction was stopped by adding $5 \mu \mathrm{l}$ sodium metabisulphite $[10 \mathrm{mg} / \mathrm{ml}$ in phos-

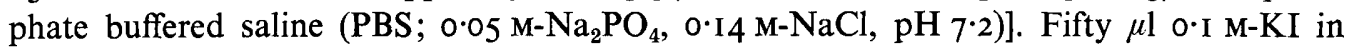
tris-gelatin (TG) buffer ( $0 . \mathrm{I}$ M-tris, $0.2 \%, \mathrm{~W} / \mathrm{v}$, gelatin, $\mathrm{pH} 7.5)$ was then added and the sample filtered through a $5 \times 70 \mathrm{~mm}$ Sephadex G-50 column pre-equilibrated and eluted with the TG buffer. The protein fraction was collected and portions stored at $-70{ }^{\circ} \mathrm{C}$.

Fresh ${ }^{125}$ I-toxin preparations were made each month, and for each preparation dilution experiments were done to ensure that the radioiodination had not influenced the cell-binding (Holmgren et al. 1974) or the $\mathrm{G}_{\mathrm{M} 1}$-binding properties (see below), and that skin toxicity (see below) was virtually unaffected.

Vibrio cholerae culture filtrate. Culture filtrate from $V$. cholerae strain 569B was obtained from the National Institutes of Allergy and Infectious Diseases, Bethesda (Lot $4493 \mathrm{G}$ ). Anti-cholera toxin. Antiserum to cholera toxin was prepared in a rabbit. Three injections 
Table I. Reagents and procedures for group-specific modification of cholera toxin

\begin{tabular}{|c|c|c|c|}
\hline Reagent & Source & Incubation conditions* & Reference \\
\hline Acetylimidazole & Sigma & $\begin{array}{l}10 \mathrm{~mm} \text { in } 0.1 \mathrm{M} \text {-phosphate } \\
\mathrm{pH} 7 \cdot 0\end{array}$ & Riordan \& Vallee (1967b) \\
\hline 5-Amino-I H-tetrazole & Merck & $\begin{array}{l}\text { Io } \mathrm{mm} \text { in } 0.1 \mathrm{M} \text {-borate } \\
\mathrm{pH} 9.2\end{array}$ & Horinishi et al. (1964) \\
\hline Bromosuccinimide & Sigma & $\begin{array}{l}0.0 \mathrm{I}-\mathrm{I} 0 \mathrm{~mm} \text { in } 0.2 \mathrm{M} \text {-acetate } \\
\mathrm{pH} 6.0\end{array}$ & $\begin{array}{l}\text { Ramachandran \& Witkop } \\
\text { (1967) }\end{array}$ \\
\hline 2,3-Butanedione & Merck & $\begin{array}{l}0 . \mathrm{I}-\mathrm{IO} \mathrm{mm} \text { in phosphate } \\
\mathrm{pH} 7.0(3 \mathrm{~h})\end{array}$ & Huang \& Tang (1972) \\
\hline 1,2-Cyclohexanedione & Pierce & $\begin{array}{l}0.1-10 \mathrm{~mm} \text { in } 0.04 \mathrm{M} \text {-sodium } \\
\text { hydroxide }\end{array}$ & Toi et al. (1967) \\
\hline $\begin{array}{l}\text { 4-Diazobenzenesulphonic } \\
\text { acid }\end{array}$ & Pfaltz \& Bauer & $\begin{array}{l}0.1-10 \mathrm{mM} \text { in } \mathrm{O} . \mathrm{I} \mathrm{M} \text {-borate } \\
\mathrm{pH} 9.2\end{array}$ & Ishikura et al. (1959) \\
\hline $\begin{array}{l}\text { I,5-Difluoro-2,4-dinitro- } \\
\text { benzene }\end{array}$ & Sigma & $\begin{array}{l}\text { Io mM in o. I M-phosphate- } \\
5 \% \text { ethanol pH } 7.0 \dagger\end{array}$ & Wold (1967) \\
\hline $\begin{array}{l}\text { 4,4-Difluoro-3,3-dinitro- } \\
\text { diphenylsulphone }\end{array}$ & Pierce & $\begin{array}{l}\text { I0 } \mathrm{mm} \text { in } 0.1 \mathrm{~m} \text { borate-10\% } \\
\text { acetone } \mathrm{pH} 9.2 \dagger\end{array}$ & Wold (I967) \\
\hline Diisopropylfluorophosphate & Koch-Light & $\begin{array}{l}\mathrm{I}-10 \mathrm{~mm} \text { in } 0.05 \mathrm{M} \text {-tris- } \\
5 \% \text { isopropanol pH } 7.5 \dagger\end{array}$ & Cohen et al. (1967) \\
\hline $\begin{array}{l}\text { Ethyl-3,3-dimethyl-amino- } \\
\text { propylcarbodiimide }\end{array}$ & Sigma & $\begin{array}{l}\mathrm{I} 0 \mathrm{~mm} \text { in } 0.15 \mathrm{M}-\mathrm{NaCl} \\
\mathrm{pH}_{4} \cdot 3\end{array}$ & Hoare \& Koshland (1966) \\
\hline $\begin{array}{l}\text { Ethyl-3,3-dimethyl-amino- } \\
\text { propylcarbodiimide and } \\
\text { glycine- } O \text {-methylester }\end{array}$ & Sigma & $\begin{array}{l}\text { As above, with } 50 \mathrm{~mm} \text {-glycine- } \\
O \text {-methylester }\end{array}$ & Hoare \& Koshland (1966) \\
\hline$N$-ethylmaleimide & Sigma & $\begin{array}{l}\text { Io } \mathrm{mM} \text { in } 0 . \mathrm{I} \mathrm{M} \text {-phosphate } \\
\text { pH } 7.0\end{array}$ & Riordan \& Vallee (1967a) \\
\hline Glutaraldehyde, grade IV & Sigma & $\begin{array}{l}0 . \mathrm{I}-\mathrm{IO} \mathrm{mM} \text { in } \mathrm{O} . \mathrm{I} \mathrm{M} \text {-phosphate } \\
\mathrm{pH} 7.0\end{array}$ & Wold (1967) \\
\hline Glyoxal & Sigma & $\begin{array}{l}\text { Io mM in } 0.2 \text { M-ethyl- } \\
\text { morphiline } \mathrm{pH} 9.2\end{array}$ & Takahashi (I968) \\
\hline $\begin{array}{l}\text { 2-Hydroxy-5-nitro-benzyl } \\
\text { bromide }\end{array}$ & Sigma & $\begin{array}{l}10 \mathrm{mM} \text { in } 0 . \mathrm{I} \mathrm{M}-\mathrm{phosphate}- \\
5 \% \text { acetone } \mathrm{pH} 7.0(\mathrm{I} \mathrm{min}) \dagger\end{array}$ & Horton \& Koshland (1967) \\
\hline Iodoacetamide & Merck & $\begin{array}{l}10-100 \mathrm{~mm} \text { in } 0.2 \mathrm{M} \text {-tris } \\
\mathrm{pH} 8.2\end{array}$ & Gurd (1967) \\
\hline 2-Mercaptoethanol & Merck & $\mathrm{I}-100 \mathrm{mM}$ in $0.2 \mathrm{M}$-tris $\mathrm{pH} 8.2$ & Hirs (1967) \\
\hline $\begin{array}{l}\text { 2-Mercaptoethanol; } \\
\text { iodoacetamide }\end{array}$ & Merck & $\begin{array}{l}\text { I00 mM-2-mercaptoethanol. } \\
\text { Thereafter Io mM iodo- } \\
\text { acetamide for } 15 \text { min at } 0^{\circ} \mathrm{C}\end{array}$ & Hirs (1967) \\
\hline $\begin{array}{l}\text { 2-Methoxy-5-nitro-benzyl } \\
\text { bromide }\end{array}$ & Sigma & $\begin{array}{l}\text { Io } \mathrm{mm} \text { in } 0 . \mathrm{I} \mathrm{M} \text {-phosphate- } \\
5 \% \text { acetone } \mathrm{pH} 7.0 \dagger\end{array}$ & Horton \& Koshland (I967) \\
\hline $\begin{array}{l}\text { S-Methylisothiourea } \\
\text { sulphate }\end{array}$ & Pfaltz \& Bauer & IO $\mathrm{mm}$ pH II $\cdot 0,4{ }^{\circ} \mathrm{C}(24 \mathrm{~h})$ & $\begin{array}{l}\text { Hughes, Saroff \& Carney } \\
\text { (I949) }\end{array}$ \\
\hline Phenanthrenequinone & Merck & $\begin{array}{l}0.00 \mathrm{I}-\mathrm{IO} \mathrm{mm} \text { in } 0.04 \mathrm{M}- \\
\mathrm{NaOH}, 5 \% \text { ethanol } \dagger\end{array}$ & Yamada \& Itano (1966) \\
\hline Phenylglyoxal & Koch-Light & $\begin{array}{l}10 \mathrm{~mm} \text { in } 0.2 \mathrm{M} \text {-ethyl- } \\
\text { morphiline } \mathrm{pH} 8.0\end{array}$ & Takahashi (1968) \\
\hline Picrylsulphonic acid & Sigma & $\begin{array}{l}0.1 \text { - } 10 \mathrm{~mm} \text { in } 0.1 \mathrm{M} \text {-borate } \\
\mathrm{pH} 9.2\end{array}$ & Okuyama \& Satake (1960) \\
\hline Succinic anhydride & Sigma & $\begin{array}{l}\text { Io } \mathrm{mm} \text { in } 0.1 \mathrm{M} \text {-phosphate } \\
\mathrm{pH} 7.0\end{array}$ & Klotz (1967) \\
\hline Tetranitromethane & Sigma & $\begin{array}{l}\text { I0 } \mathrm{mm} \text { in } 0.2 \mathrm{M} \text {-tris }-5 \% \\
\text { ethanol pH } 8 \cdot 2 \dagger\end{array}$ & $\begin{array}{l}\text { Riordan, Sokolovsky \& } \\
\text { Vallee (I966) }\end{array}$ \\
\hline
\end{tabular}


of $30 \mu \mathrm{g}$ of toxin were given subcutaneously at intervals of 3 weeks; the blood was collected two weeks after the last injection. The serum contained precipitating antibodies against the $\mathrm{L}$ as well as the $\mathrm{H}$ subunits of the toxin as shown by double diffusion-in-gel analyses (Holmgren \& Lönnroth, 1975).

Ganglioside $G_{\mathrm{M} 1}$. The ganglioside $\mathrm{G}_{\mathrm{M} 1}$ was purified from human brain by $\mathrm{L}$. Svennerholm, Göteborg, Sweden (Svennerholm, 1972).

Protein modification. Table I presents the amino acid 'specific' protein modification reagents used, their sources, and the incubation conditions employed for toxin treatment. A $12 \mu \mathrm{M}(\mathrm{I} \mathrm{mg} / \mathrm{ml})$ solution of cholera toxin was prepared by dilution in distilled water and was further diluted $\mathrm{I}: \mathrm{IO}$ in the appropriate buffer containing the protein-modifying reagent. The mixture, total volume $50 \mu \mathrm{l}$, was incubated as specified for each reagent (Table I). The standard reagent concentration was $10 \mu \mathrm{M}$, but if an effect on any of the toxin properties studied was observed then additional toxin derivatives were prepared using other reagent concentrations. The reaction was stopped and the reactants separated by filtration through a $5 \times 70 \mathrm{~mm}$ Sephadex G-I5 column. The protein fraction was collected and diluted in TG buffer to a final concentration of $0.024 \mu \mathrm{M}(2 \mu \mathrm{g} / \mathrm{ml})$ cholera protein. It was divided into small portions which were stored at $-20{ }^{\circ} \mathrm{C}$ until tested at multiple concentrations. The control test for each reaction consisted of incubating toxin under the appropriate conditions but without the modifying reagent. The control was gel-filtered, diluted and stored like the test preparation.

Lyophilized $V$. cholerae culture filtrate was dissolved to $200 \mathrm{mg} / \mathrm{ml}$ in distilled water, dialysed against $0.05 \mathrm{M}-\mathrm{NaCl}$ and concentrated to give a solution containing $20 \mathrm{mg}$ bacterial protein $/ \mathrm{ml}$. This preparation, which contained approximately $0.2 \mathrm{mg}$ cholera toxin $/ \mathrm{ml}$, was treated with chemical reagents as described for the purified toxin.

Enzymic treatment. Three enzymes (Sigma) were used: leucine aminopeptidase type III $(86 \mathrm{u} / \mathrm{mg})$ at a final concentration of $0.67 \mathrm{mg} / \mathrm{ml}$, carboxypeptidase A DFP $(47 \mathrm{u} / \mathrm{mg})$ at $7 \mathrm{mg} / \mathrm{ml}$, and trypsin type III (IOO $\mathrm{u} / \mathrm{mg}$ ) at $\mathrm{I} \mathrm{mg} / \mathrm{ml}$. Each enzyme was incubated with $3.8 \mu \mathrm{M}$-cholera toxin $(0.33 \mathrm{mg} / \mathrm{ml})$ at $37^{\circ} \mathrm{C}$ for $4 \mathrm{~h}$ in $0.1 \mathrm{M}-N$-ethylmorphiline- $\mathrm{HCl}, 0.00 \mathrm{I} \mathrm{M}$ $\mathrm{MgCl}_{2}, \mathrm{pH} 8 \cdot 4$, with or without $2 \mathrm{M}$-urea. The reaction was stopped by a 250 -fold dilution of the sample in $0.2 \mathrm{M}$-ammonium formate $\mathrm{pH}_{4} .5$, containing $0.2 \%(\mathrm{w} / \mathrm{v})$ gelatin. The solution was immediately divided into small portions which were stored at $-70^{\circ} \mathrm{C}$. Three controls were prepared for each test: (i) a portion of the enzyme and toxin mixture taken at zero time, (ii) the enzyme, and (iii) the toxin incubated separately under the same conditions as the test sample.

Toxicity assay. The toxic activities of the toxin derivatives and of their control preparations were determined by testing multiple concentrations with the rabbit intradermal assay (Craig, I965). To minimize errors due to the different sensitivities of individual rabbits, treated and control toxin were always compared in the same animal. The concentration required for a blueing reaction $7 \mathrm{~mm}$ in diameter (one blueing dose) was calculated for each preparation and the effect on toxicity of each chemical treatment expressed as the ratio of control to test values. A ratio of $\mathrm{I} \cdot \mathrm{O}$ meant no effect and a ratio of $0 \cdot 0$ a complete abolition of toxicity.

Combined assay of $G_{\mathrm{M1}}$ - and antibody-binding. The $\mathrm{G}_{\mathrm{M1}}$ sorbent immunoassay technique (Holmgren, 1973) measures the in vitro binding capacity of cholera toxin to polystyreneattached $\mathrm{G}_{\mathrm{M} 1}$ ganglioside, combined with the ability of the bound toxin to bind subsequently added specific antibody; the principal steps are shown in Fig. I (a). Multiple concentrations of treated and control toxin preparations were assayed and the values expressed as extinction change per $100 \mathrm{~min}$, plotted against the concentration. The concentration $C_{0}$ of the control 


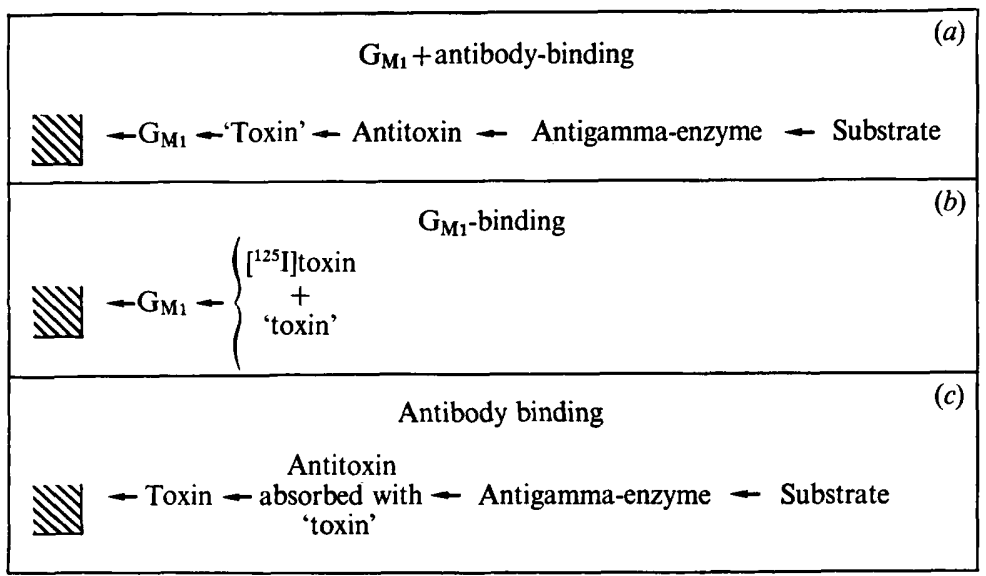

Fig. I. Reaction steps in the combined and separate assays of cholera toxin binding to $\mathbf{G}_{\mathbf{M}_{1}}$ ganglioside or specific antibody in vitro: (a) ganglioside sorbent immunoassay for measurement of combined $\mathrm{G}_{\mathrm{M} 1^{-}}$and antibody-binding; $(b)$ competitive ganglioside sorbent radioassay for measurement of

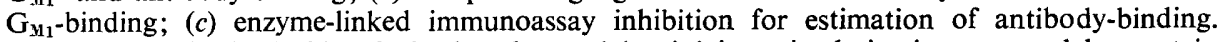
Hatched area is the inside of plastic tube, and 'toxin' is toxin derivative prepared by protein modification. The anti-rabbit IgG (antigamma) was prepared in a goat.

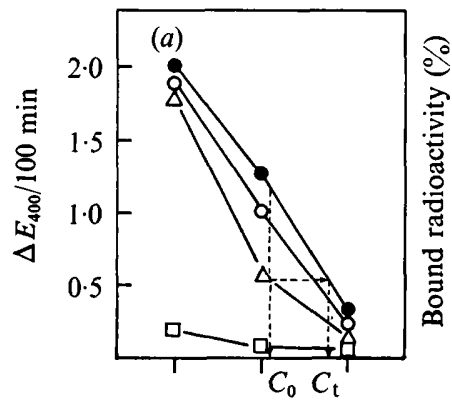

$0.2 . \quad 0.04 \quad 0.008$
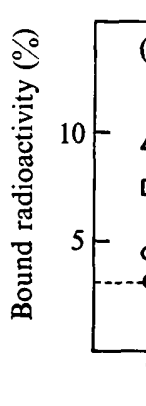

$\begin{array}{ccc}2 & 0.4 & 0.08 \\ \text { Toxin } & \text { concn }(\mu \mathrm{g} / \mathrm{ml})\end{array}$

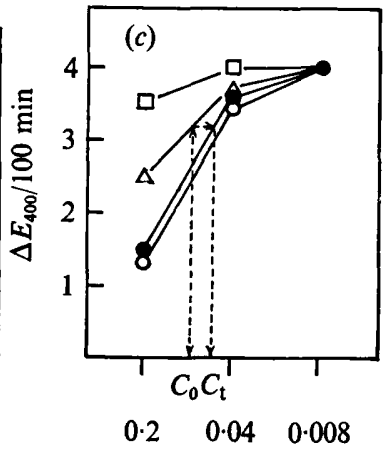

Fig. 2. In vitro assays of control cholera toxin and of toxin derivatives prepared by treatment with different concentrations of picrylsulphonic acid: 0 , o $\mathrm{mM}$ (control toxin); $0,0 . \mathrm{I} \mathrm{mM} ; \triangle, \mathrm{I} \mathrm{mM}$; $\square, 10 \mathrm{~mm}$. Dotted lines and the arrows show how the concentration $C_{0}$ of untreated toxin and the concentration $C_{\mathrm{t}}$ of one of the toxin derivatives are calculated. These concentrations are used to express the relative activity of the toxin derivative compared with the control preparation: $(a)$ relative $\mathrm{G}_{\mathrm{M}_{1}}$ + antibody-binding activity $\left(=C_{\mathrm{t}} / C_{0}\right) ;(b)$ relative $\mathrm{G}_{\mathrm{M1}_{1}}$-binding activity $\left(=C_{0} / C_{\mathrm{t}}\right)$; (c) relative antibody-binding activity $\left(=C_{\mathrm{t}} / C_{0}\right)$.

preparation which would give a half-maximal extinction change was calculated. The extinction value for the treated preparation at this concentration was transposed to the control preparation curve, see Fig. $2(a)$. $C_{\mathrm{t}}$ is the concentration of untreated toxin that gives the same extinction value as treated toxin at concentration $C_{0}$. The relative $\mathrm{G}_{\mathrm{M} 1}+$ antibodybinding activity of the treated preparation is expressed by the ratio $C_{t} / C_{0}$, where a ratio of $\mathrm{I} \cdot 0$ means no effect by the modification procedure and 0.0 a complete abolition of one or both of the properties tested.

Assay of $G_{M 1}$-binding. $\mathrm{G}_{\mathrm{M1}}$-binding was measured with a $\mathrm{G}_{\mathrm{M1}}$-sorbent radioassay, in which unlabelled treated toxin competed with ${ }^{125}$ I-toxin for binding to solid-phase $\mathrm{G}_{\mathrm{M} 1}$ ganglioside (Fig. I $b$ ). As described for the $\mathrm{G}_{\mathrm{M} 1}$-sorbent immunoassay, but with a $0.2 \mathrm{ml}$ volume, the $G_{M 1}$ ganglioside was coated to the inside of plastic tubes and the non-bound fraction washed 
away with PBS containing $0.05 \%$ Tween 20 (PBS-Tween). In a total volume of $0.2 \mathrm{ml}$, treated toxin in various amounts was added followed by $10 \mu \mathrm{l}$ of a fixed amount $(0.002 \mu \mathrm{g})$ of ${ }^{125} \mathrm{I}$-toxin. The tubes were incubated at $23{ }^{\circ} \mathrm{C}$ for $2 \mathrm{~h}$ in a roller drum, washed $3 \times 3 \mathrm{~min}$ with PBS-Tween and tested for radioactivity in a gamma scintillator (Packard Instrument Corp.). The values for percentage of bound radioactivity were plotted against total toxin concentration. The curve intercepts with the background level were used to indicate the concentration of control $\left(C_{0}\right)$ or test toxin preparations $\left(C_{\mathrm{t}}\right)$ required for saturation of the $\mathrm{G}_{\mathrm{M1}}$ receptors (Fig. $2 b$ ). The relative $\mathrm{G}_{\mathrm{M1}}$-binding activity of the test protein is expressed as the ratio $C_{0} / C_{t}$, where I.0 means unchanged activity as compared with the control preparation and 0.0 means no activity.

Assay of antibody-binding. An inhibition technique was used. Mixtures of different concentrations of treated or control toxin preparation and a specific dilution of antitoxin antiserum in PBS -Tween were incubated in a total volume of $0.5 \mathrm{ml}$, at $4{ }^{\circ} \mathrm{C}$ overnight in glass tubes. These mixtures (absorbed antiserum) were transferred to plastic tubes which had been coated with toxin (Fig. I $c$ ), and the tubes incubated in a roller drum at $23{ }^{\circ} \mathrm{C}$ for 5 h (Holmgren \& Svennerholm, 1973). This allowed binding of the antitoxin antibodies to the solid-phase toxin, unless the combining sites of the antibodies had already been occupied by the toxin during the preincubation. After washing the tubes with PBS-Tween, bound antibodies were measured by reacting them, first with enzyme-conjugated anti-IgG and then, after washing, with substrate for the enzyme in the same manner as in the $\mathrm{G}_{M 1}$-sorbent immunoassay. Extinction values were plotted against concentration of treated and control toxin preparation and the inhibitory concentrations $C_{0}$ and $C_{\mathrm{t}}$ were derived as shown in Fig. $2(c)$ and described for the $\mathrm{G}_{\mathrm{M} 1}$-sorbent immunoassay. The relative antibody-binding activity of treated as compared with control toxin preparation is given as the ratio $C_{\mathrm{t}} / C_{0}$ where $\mathrm{I} \cdot \mathrm{O}$ means intact and 0.0 abolished activity.

Electrophoresis in polyacrylamide. Two types of electrophoresis in polyacrylamide gel were used: conventional (p.g.e.) and with added sodium dodecyl sulphate, SDS (SDS-p.g.e.). Our p.g.e. method was similar to that of Finkelstein, Fujita \& Lo Spalluto (197I) except that we used flat beds (plates), and pre-electrophoresis was performed for $2 \mathrm{~h}$ before application of the samples. The SDS-p.g.e. technique in flat beds has been described previously (Lönnroth \& Holmgren, I973). Before SDS-p.g.e., the proteins were incubated with $2 \%$ SDS, $8 \mathrm{M}$-urea and $0.04 \mathrm{M}$-iodoacetamide at $53{ }^{\circ} \mathrm{C}$ for $\mathrm{I} 5 \mathrm{~min}$.

\section{RESULTS}

\section{Sensitivity and accuracy of methods}

The rabbit skin test is an established quantitative assay of cholera toxin activity (Craig, 1965). The overall mean concentration of unmodified toxin required for I blueing dose was $0.002 \mu \mathrm{g} / \mathrm{ml}$. In the three in vitro methods for measuring the receptor-binding and/or the antigenic properties of cholera toxin or toxin derivatives, the mean concentrations of unmodified toxin giving the indicated activity were $0.044 \mu \mathrm{g} / \mathrm{ml}$ for the combined $\mathrm{G}_{\mathrm{M} 1}+$ antibody-binding immunoassay, $0.80 \mu \mathrm{g} / \mathrm{ml}$ for the $\mathrm{G}_{\mathbf{M 1}}$-binding radioassay, and $0.18 \mu \mathrm{g} / \mathrm{ml}$ for the antibody-fixation immuno-inhibition assay.

The variation in the determinations of relative activity was less than $1 \cdot 2$-fold for the $\mathrm{G}_{\mathrm{M} 1}+$ antibody-binding activity and less than $\mathrm{I} \cdot 5$-fold for the other activites $(P<0.05)$. Over twenty of the toxin derivatives were prepared more than once and their relative activities were all within the experimental limits of the test methods, indicating a high degree of reproducibility. 
Table 2. Effects of chemicals on the activities of cholera toxin

Here, 0.0 indicates a relative activity below 0.05 .

A. Amino group reagents

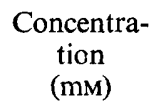

Picrylsulphonic acid

Succinic anhydride

$S$-methylisothiourea sulphate

B. Cysteine and cystieine reagents

$N$-ethylmaleimide

Iodacetamide

2-Mercaptoethanol

2-Mercaptoethanol+

iodoacetamide

C. Arginyl reagents

Phenylglyoxal

Glyoxal

I,2-Cyclohexanedione

2,3-Butanedione

Phenanthrenequinone

5-Amino-IH-tetrazole

4-Diazobenzenesulphonic acid

Tetranitromethane

E. Other group-specific reagents

Ethyl-3,3-dimethyl-aminopropylcarbodiimide

As above with $(50 \mathrm{~mm})$ glycine- $O$ methylester

IO

D. Aromatic amino acid reagents

2-Hydroxy-5-nitrobenzyl bromide

IO

Acetylimidazole

10

Bromosuccinimide

IO

IO

I

10

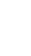

Binding activity

$\overbrace{\begin{array}{c}\mathbf{G}_{M 1}+ \\ \text { antibody }\end{array} \quad G_{M_{1}} \quad \text { Antibody }}$

$\begin{array}{lll}0.0 & 0.0 & 0.3 \\ 0.4 & 0.0 & 0.7 \\ 0.8 & 0.6 & 1.1 \\ 1.0 & 0.8 & 1.3 \\ 0.2 & - & 0.7 \\ 0.3 & - & 0.5\end{array}$

I 3

0.7

I.O

$\mathrm{I} \cdot 2$

$\mathrm{I} \cdot 5$

0.6

0.8

I. 4

$1 \cdot 5$

$0 \cdot 2$

I $\cdot$ I

0.6

I.I

I.9

0.7

$\mathrm{I} \cdot 4$

0.6

0.8

0.0

$\begin{array}{lll}1.8 & - & - \\ 0.9 & - & - \\ \mathrm{I} .5 & \mathrm{I} \cdot 2 & \mathrm{I} \cdot 0 \\ 3.5 & 1.3 & 3.7 \\ 3.5 & 1.3 & 2.0 \\ 0.0 & 0.0 & 0.4 \\ - & 1.0 & 0.2 \\ - & 1.0 & - \\ 0.0 & - & 0.4 \\ 0.3 & 0.1 & 0.5 \\ 0.8 & 1.0 & 0.7 \\ 1.0 & - & 1.0\end{array}$

$2 \cdot 2$

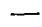

$2 \cdot 8$

$1 \cdot 0$

I.O

$1 \cdot 0$

I 0

0.0

0.0

0.0

$0.1 \quad 0.0$

$0.01 \quad I .0$

0.0

0.0

$2 \cdot 0$

$10 \quad 1.0$

$2 \cdot 0$

0.7

0.0

0.0

I. 3

$-$

0.0

0.0

0.0

$\mathrm{I} \cdot \mathrm{O}$

$-$

$-$

0.0

I. O

0.2

$5 \cdot 2$

I.5

I $\cdot 0$

$1 \cdot 0$

0.7

$\mathbf{I} \cdot 0$

$1 \cdot 0$ 
Table 2. Cont.

E. Other group-specific reagents (cont.)

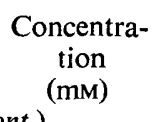

Glutaraldehyde

1,5-Difluoro-2,4-dinitrobenzene

4,4-Difluoro-3,3-dinitro-

phenylsulphone

Diisopropylfluorophosphate

IO
I
$0 \cdot 1$
10
10
10
I
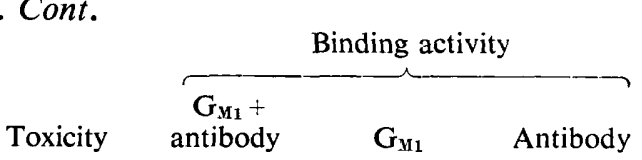

F. Various reagents

Leucine aminopeptidase*

Without urea With urea

Carboxypeptidase*

Without urea

With urea

Trypsin*

Without urea

With urea

Sodium hydroxide

1000

100

40

IO

Toxicity

antibody

$\mathrm{G}_{\mathrm{M1}_{1}}$

Antibody

Sodium dodecylsulphate

0.1
1.0
$I .0$
0.1
$I .0$
0.0
$I .0$

0.3
$I \cdot I$
$I \cdot 0$
0.3
$1 \cdot 0$

0.3
0.8

0.0

$0 \cdot \mathrm{I}$

$\begin{array}{ll}0.7 & 0.9 \\ 1 \cdot 1 & 0.9\end{array}$

$\begin{array}{ll}0.7 & 0.9 \\ I \cdot I & 0.9\end{array}$

$0 \cdot 1$

$\mathrm{I} \cdot \mathrm{O}$

$0 \cdot 8$

$0 \cdot 1$

-

0.0

$1 \cdot 0$

$\begin{array}{rr}100 & 0.0 \\ 10 & 0.0 \\ I & 0.0\end{array}$

$\begin{array}{ll}I .0 & 0.5 \\ I .0 & 0.7 \\ I .0 & 0.8 \\ 0.0 & 0.9 \\ I .0 & -. \\ 0.0 & 3.3 \\ 0.0 & 0.1 \\ 0.0 & 0.2 \\ 0.2 & 0.4 \\ 1.0 & 5.2 \\ 0.0 & 0.7 \\ 0.0 & 0.8 \\ 0.0 & 0.8\end{array}$

$I \cdot 0$
-
$1 \cdot 0$
$1 \cdot 0$
-
$I \cdot 0$
$0 \cdot 0$
$0 \cdot 2$
$0 \cdot 8$
$7 \cdot 1$
$0 \cdot 1$
$I \cdot 4$
$I \cdot 0$

$1 \cdot 0$

* The relative activities of the enzyme-treated preparation are based on comparison with those of the control preparation (i) described in Methods; controls (i) and (iii) gave identical values and control (ii) had no activity in the tests.

The activities of the various control toxin preparations were compared with those of purified toxin diluted directly in TG buffer. Of the buffers employed to modify the protein, only the $0.04 \mathrm{M}$-sodium hydroxide used for 1,2-cyclohexanedione and phenanthrenequinone had by itself any effect on the toxin's reactivity in the various tests (see Table $2 \mathrm{~F}$ ).

\section{Chemical modification of cholera toxin}

Amino-group specific reagents. Reagents which modify amino groups in proteins do so by attaching covalently to free amino groups of lysine and to the $N$-terminal amino acid(s). Different concentrations of picrylsulphonic acid caused a concomitant reduction of toxicity and $\mathrm{G}_{\mathrm{M} 1}$-binding activity of cholera toxin, whereas the antibody-fixing activity was slightly more resistant (Table $2 \mathrm{~A}$ and Fig. 2). Succinic anhydride and, to a lesser extent, S-methylisothiourea, had similar effects (Table $2 \mathrm{~A}$ ).

Cysteine and cystine residue specific reagents. Toxin was treated with chemicals that react with free sulphhydryl groups on cysteine or with cystine disulphide bridges (Table $2 \mathrm{~B}$ ). $N$-ethylmaleimide and iodoacetamide, which both attach covalently to free sulphhydryl groups, did not affect any of the measured properties of the toxin. In contrast, the disulphide bridge splitting reagent 2-mercaptoethanol (alone or with iodoacetamide) decreased the toxic activity, and at higher concentrations destroyed it completely, without changing the $\mathrm{G}_{\mathrm{MI}}{ }^{-}$and antibody-binding properties to the same extent.

Arginyl specific reagents. Treatment of toxin with arginyl specific reagents had differential 
effects on the properties measured (Table $2 \mathrm{C}$ ). Phenylglyoxal and glyoxal had no effect, whereas the other three reagents used that also contained a diketene structure inhibited the toxicity without decreasing other properties concomitantly. The most divergent effects were caused by I,2-cyclohexanedione, which inhibited toxicity but enhanced the toxin's reactivity in the combined $\mathrm{G}_{\mathrm{M1}_{1}}+$ antibody-binding assay. The latter effect may have been due to an elevated antibody-fixing capacity with the $\mathrm{G}_{\mathrm{M1}}$-binding ability remaining unchanged (Table 2C). Enhanced antibody-binding ability was seen after treatment with several reagents of various specificities. 2,3-Butanedione (I $\mathrm{mM}$ ) produced the most pronounced differences between the $G_{M 1}$-binding and the antibody-fixing properties of the toxin: the former property was not affected whereas the immunological reactivity was decreased. Phenanthrenequinone was the most potent detoxifying reagent of all, but affected the $\mathrm{G}_{\mathrm{M1}}$ - and antibody-binding qualities only at high concentration.

Reagents reacting with aromatic amino acids. Toxin was treated with reagents which are more or less specific for aromatic amino acids (Table $2 \mathrm{D}$ ). The tryptophan-specific chemicals 2-hydroxy-5-nitrobenzyl bromide and 2-methoxy-5-nitrobenzyl bromide, also named Koshland's reagents $I$ and 2, decreased neither toxicity nor the $G_{M I}+$ antibody-binding properties of the toxin. Acetylimidazole which is a tyrosine-specific reagent, 5 -amino-I-Htetrazole which modifies tyrosine and histidine, and tetranitromethane which binds to tyrosine and cysteine residues behaved similarly. The latter reagent was repeatedly found to potentiate both the toxicity and the $\mathrm{G}_{\mathbf{M} 1}+$ antibody-binding capacity. Bromosuccinimide (reactive with tryptophan $>$ tyrosine $>$ histidine at $\mathrm{pH} \mathrm{6.0)}$ ) and 4 -diazobenzenesulphonic acid (reactive with tyrosine and histidine) destroyed both the toxicity and the $\mathrm{G}_{\mathrm{M} 1}+$ antibody-binding capacity.

Other group-specific reagents. Toxin derivatives were prepared by treatment with a variety of reagents with different specificities (Table $2 \mathrm{E}$ ). Carbodiimides alter, specifically, amino acids containing a free carboxyl group, i.e. glutamic and aspartic acid and the carboxyterminal amino acid. Ethyl-3,3-dimethyl-aminopropylcarbodiimide, which was tested with and without glycine- $O$-methyl ester, did not affect either the toxicity or the $\mathrm{G}_{\mathrm{MI}}+$ antibodybinding capacity. Three bifunctional reagents were tested: glutaraldehyde and I,5-difluoro2,4-dinitrobenzene, both of which decreased the toxic, $\mathrm{G}_{\mathrm{M1}}$ - and antibody-binding activities, and 4,4-difluoro-3,3-dinitrodiphenylsulphone which had no effect on any of these properties. Diisopropylfluorophosphate is a widely used serine esterase inhibitor in enzymology; it has a reported specificity for the serine group responsible for esterase activity, but at higher concentration it also has an affinity for tyrosine and glutamine residues (Cohen, Oosterbaan $\&$ Berends, 1967). Only at these higher concentrations (IO mM) of diisopropylfluorophosphate was there any effect on the cholera toxin; toxicity was abolished, together with $\mathrm{G}_{\mathrm{M1}}$ - and antibody-binding capacities. This indicates that the toxin itself does not act as a serine esterase, since the toxic activity then would probably have been much more labile than the two other properties.

Other types of reagents. The toxin was treated with two exopeptidases, leucine aminopeptidase and carboxypeptidase $A$, which digest protein from the amino and carboxy terminal ends respectively, and with the endopeptidase trypsin (Table 2 F). None of these enzymes had any influence, even at high concentrations, on the toxic or the $\mathrm{G}_{\mathrm{M1}}$ - or antibodyfixing activities of the toxin when tested in ordinary buffer. However, in the presence of $2 \mathrm{M}$-urea both carboxypeptidase $A$ and trypsin abolished toxicity without affecting $\mathrm{G}_{\mathrm{M}^{-}}$ and antibody-fixing properties.

Sodium hydroxide ( 0.04 to I $\mathrm{M}$ ) also inhibited both toxicity and $\mathrm{G}_{\mathrm{M} 1}+$ antibody-binding capacity. When $\mathrm{G}_{\mathrm{M1}}$-binding and antibody-fixation were tested separately it appeared that 


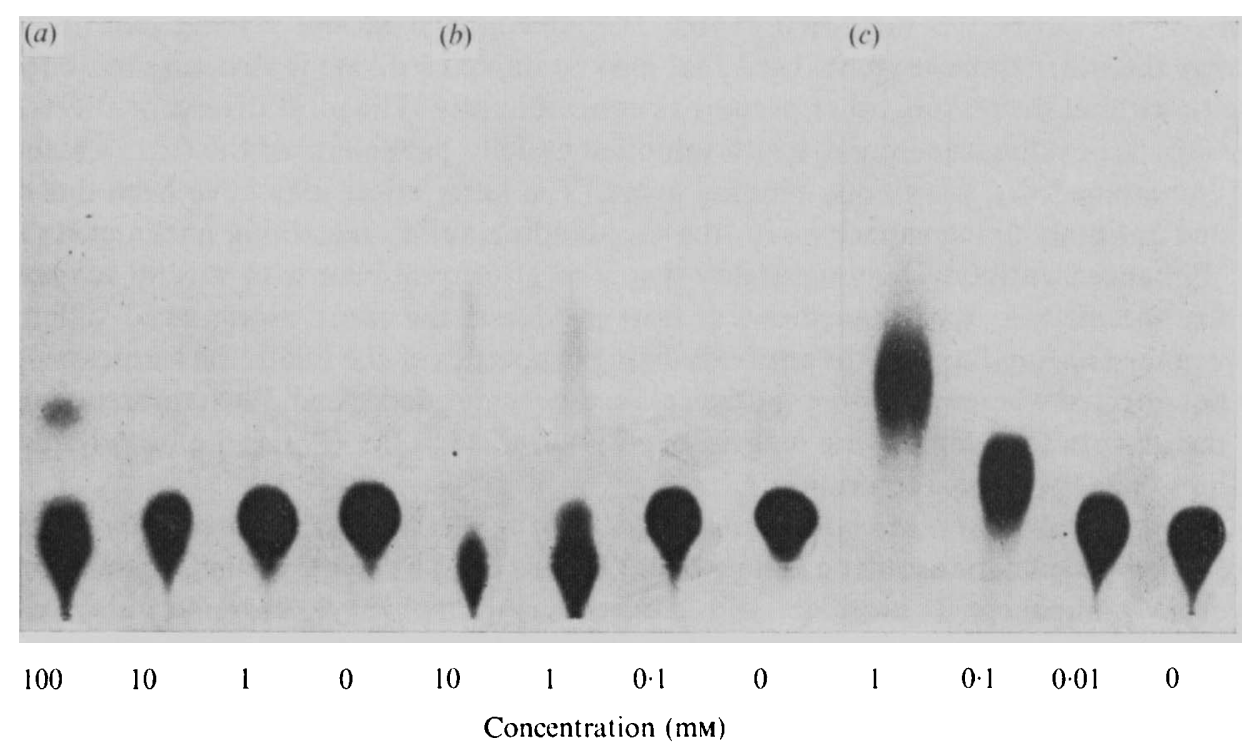

Fig. 3. Polyacrylamide gel electrophoresis of control toxin and toxin treated with various concentrations of (a) 2-mercaptoethanol, (b) SDS and (c) picrylsulphonic acid. Anode at top.

the most pronounced effect was on antigenicity. With $0 \cdot 0 \mathrm{I} \mathbf{M}$ - sodium hydroxide a selective increase of $\mathrm{G}_{\mathrm{M} 1}$-binding capacity of the toxin was produced.

Sodium dodecylsulphate has previously been used for disaggregation of the toxin into its subunits (Lönnroth \& Holmgren, 1973). It abolished toxicity but had little effect on the $\mathrm{G}_{\mathrm{M} 1^{-}}$and antibody-binding activities of the toxin.

\section{Behaviour of modified toxin in polyacrylamide electrophoresis}

SDS-p.g.e. separates the non-covalently linked subunits of cholera toxin into two protein bands representing the fast-migrating $L$ subunit, molecular weight about 8000 , and the slower-moving $\mathbf{H}$ subunit, molecular weight 28000 (Lönnroth \& Holmgren, 1973). Any change in migration speed after treatment would imply that covalent bonds had been generated or broken between or in the peptides. In p.g.e. the toxin migrates as a single band with a relatively slow mobility. Separated $\mathbf{H}$ subunit and $\mathrm{L}$ subunit complexes, corresponding to choleragenoid, migrate faster and slower, respectively, than the intact toxin (unpublished). A changed banding pattern in p.g.e. after treatment would suggest a change in aggregation state and/or in the net charge of the toxin.

A number of toxin derivatives were examined both by electrophoresis and in the toxicity assay, to test whether effects on toxic activity induced by the chemical treatment were due to changes in the aggregation state of the toxin. The effect of SDS modification on toxicity was paralleled by a changed migration in p.g.e.; the single band of untreated toxin was replaced by a faster-moving component probably representing $\mathbf{H}$ subunit negatively charged by the SDS groups, and a slower material which migrated like aggregated L subunit (Fig. 3) 2-Mercaptoethanol also changed toxicity and the behaviour in p.g.e. concomitantly (Table 3). A similar pattern as described for SDS-treated derivatives was seen except that the fastmoving component, devoid of the negative SDS-groups, had the same migration rate as isolated $\mathrm{H}$ subunit, and the slower component showed more tailing (Fig. 3). In SDS-p.g.e. the effect was visible only at higher concentrations of 2-mercaptoethanol than those which 
Table 3. Effect of modification on cholera toxin studied by polyacrylamide gel electrophoresis with and without SDS

\begin{tabular}{|c|c|c|c|c|}
\hline \multirow[b]{2}{*}{ Reagent } & \multirow{2}{*}{$\begin{array}{c}\text { Concentration } \\
(\mathrm{mM})\end{array}$} & \multicolumn{3}{|c|}{ Effect on } \\
\hline & & SDS-p.g.e.* & P.g.e. $\dagger$ & Toxicity \\
\hline SDS & $\begin{array}{c}10 \\
\text { I } \\
\text { O. I }\end{array}$ & & $\begin{array}{l}+ \\
+ \\
-\end{array}$ & $\begin{array}{l}+ \\
+ \\
-\end{array}$ \\
\hline 2-Mercaptoethanol & $\begin{array}{r}100 \\
10 \\
\text { I }\end{array}$ & $\begin{array}{l}+ \\
-\end{array}$ & $\begin{array}{c}+ \\
\stackrel{+}{+}) \\
-\end{array}$ & $\begin{array}{l}+ \\
+ \\
-\end{array}$ \\
\hline Bromosuccinimide & I & - & - & + \\
\hline Picrylsulphonic acid & $\begin{array}{l}\text { I } \\
\text { O.I } \\
\text { O.OI }\end{array}$ & + & $\begin{array}{c}+ \\
+ \\
(+)\end{array}$ & $\begin{array}{l}+ \\
-\end{array}$ \\
\hline I,2-Cyclohexanedione & $\mathbf{I}$ & - & - & + \\
\hline Phenanthrenequinone & $\begin{array}{l}10 \\
0.1\end{array}$ & $\begin{array}{l}+ \\
-\end{array}$ & - & $\begin{array}{l}+ \\
+\end{array}$ \\
\hline
\end{tabular}

diminished the toxicity. At these higher concentrations a split of the $\mathrm{H}$ subunit into probable half-molecules takes place (Lönnroth \& Holmgren, 1973; Holmgren \& Lönnroth, 1975).

Bromosuccinimide (1 mM, pH 6.0), which has been reported to cleave peptides at acid pH (Ramachandran \& Witkop, 1967), had no visible effect on the behaviour of the toxin in any of the electrophoretic tests, despite a total inhibitory influence on all the functional properties studied (Table 3). I,2-Cyclohexanedione (I mM) also did not affect the electrophoretic patterns, although differential effects were seen on toxicity and $G_{m 1}+$ antibodybinding. Increasing concentrations of picrylsulphonic acid progressively increased the mobility of the toxin in p.g.e., which probably was due to electroneutralization of positively charged lysine groups (Fig. 3). The aggregation state of toxin treated with this reagent seemed unaffected in the p.g.e. analyses; in SDS-p.g.e. the proportion of $\mathrm{L}$ and $\mathrm{H}$ subunit material was unchanged but the $\mathrm{L}$ subunit had a slower mobility than usual. At high concentration, phenanthrenequinone had an effect similar to that of 2-mercaptoethanol in SDS-p.g.e., i.e. it cleaved the $\mathrm{H}$ subunit, but it also abolished toxicity at lower concentrations, which had no effect on the behaviour of the toxin in either p.g.e. or SDS-p.g.e.

\section{Modification of $V$. cholerae culture filtrate}

Preliminary studies with $V$. cholerae culture filtrate showed that the in vitro assays of the $\mathrm{G}_{\mathrm{M} 1}$ receptor-binding and the antibody-fixing properties of purified toxin could be used with similar accuracy for evaluating the crude material (Holmgren, 1973; Holmgren \& Svennerholm, 1973). Although dialysed and concentrated $V$. cholerae culture filtrate contained large amounts of other bacterial proteins, after treatment with four reagents ( $N$-ethylmaleimide, phenylglyoxal, picrylsulphonic acid and I,2-cyclohexanedione, all at $10 \mathrm{~mm}$ ) which had different residue specificity and different effects on the tested properties of purified cholera toxin, the derivatives gave the same results as those produced with treated purified toxin. 


\section{DISCUSSION}

The techniques described here, which can be applied to small quantities of purified or crude toxin preparations, may be useful for comparative studies between cholera toxin and other bacterial enterotoxins. Some of the treatments decreased the ability of cholera toxin to bind in vitro to the ganglioside $\mathrm{G}_{\mathrm{M1}}$ and caused a concomitant reduction in toxicity. These effects were not unexpected, since recent studies strongly indicate that the $\mathrm{G}_{\mathrm{M} 1}$ ganglioside functions as membrane receptor for the toxin in various target cells (Holmgren et al. 1973; King \& van Heyningen, 1973; Cuatrecasas, 1973 $b$; Holmgren et al. 1975). The toxicity, however, was also destroyed by a few reagents which had no influence on the $\mathrm{G}_{\mathrm{M} \mathbf{1}}$-binding ability. This supports the previous finding that structures which are not involved in cellbinding are required for the expression of toxic activity. The $\mathrm{H}$ subunit of cholera toxin is needed for toxic activity but is not binding either to $\mathrm{G}_{\mathbf{M 1}}$ ganglioside in vitro or to target cells (Lönnroth \& Holmgren, 1973; Cuatrecasas et al. 1973; Holmgren et al. 1974; van Heyningen, 1974; Holmgren \& Lönnroth, 1975). It seems likely, therefore, that those reagents which had a selective effect on the toxic activity affected principally the $\mathrm{H}$ subunit in a manner which prevented it inducing the presumed key event in the toxic action, i.e. activation of membrane adenylate cyclase. The decrease in toxicity caused by reagents such as 2-mercaptoethanol and SDS illustrates the importance of assembled subunits for biological activity (Lönnroth \& Holmgren, 1973). Two of the other three reagents which selectively destroyed the toxicity did not, at the concentrations used, affect the quaternary structure of the toxin as studied by gel electrophoresis. This suggests that the loss in biological activity of the toxin was caused by a critical modification in situ of the $\mathrm{H}$ subunit. Holmgren et al. (1974) and Holmgren \& Lönnroth (I975) found that all of the receptor-binding as well as most of the antigenic properties of the toxin reside in the same type of subunit. This finding is supported by the present results from the separate testing of $G_{\mathbf{M 1}}$-binding and antibody-fixation of toxin derivatives. Most reagents had a concomitant effect on these properties, indicating a close structural association between the receptor-binding and the antigenic sites. A few reagents however, like 2-mercaptoethanol (I00 mM), picrylsulphonic acid (I mM) or 2,3-butanedione (I mM), affected these properties differently.

This information on the gross relationships between the toxic, receptor-binding and antigenic sites of cholera toxin, is supplemented by information on the type of residues contributing to the structural arrangement of these sites. However, such interpretations are preliminary, since with the limited amounts of toxin available it has not been possible to assess the efficiency of the chemical treatments in terms of specificity and extent of residue modification. Amino group reagents such as picrylsulphonic acid, succinic anhydride, S-methylisothiourea, glutaraldehyde, and I,5-difluoro-2,4 dinitrobenzene destroyed the properties of toxicity and receptor + antibody-binding concomitantly. Since leucine aminopeptidase, which digests proteins from the amino terminal end, did not affect any of these features of the toxin, with or without urea, even at high concentration, it is probably the modification of lysine groups which is responsible for the observed changes in toxin properties induced by amino group reagents. The $\mathrm{G}_{\mathbf{M 1}}$-binding quality seemed to be more sensitive than the antibody-binding capacity, which suggests that lysine groups are involved in the binding of toxin to the acidic $\mathrm{G}_{\mathrm{M}}$ ganglioside receptor. This interpretation is consistent with data on the amino acid composition of cholera toxin, and on a 'natural' cholera toxoid, choleragenoid (Finkelstein, 1973). The latter protein has the same composition as the toxin except for lacking the 'toxic' H subunit (Lönnroth \& Holmgren, 1973). Therefore, the reported finding that choleragenoid contains $80 \%$ of the lysine residues of the toxin demon- 
strates that lysine residues are particularly frequent in the receptor-binding $\mathrm{L}$ subunit aggregate portion of the toxin. Three types of toxin derivatives prepared by reagents which are specific for arginine lost toxicity but retained intact $\mathrm{G}_{\mathbf{M} 1^{-}}$and antibody-binding qualities. Since arginine is much more abundant in the toxin than in choleragenoid (Finkelstein, 1973), i.e. it is present predominantly in the 'toxic' subunit $\mathbf{H}$, and since tests with two of our derivatives showed that the chemical modification had not changed the aggregation state of the toxin, we believe that arginine residues of the toxin may be involved in the 'toxic site' inducing activation of target cell adenylate cyclase.

Reagents with the same reported specificity sometimes had quite different effects on cholera toxin. Variation in reactivity of a functional group is a common observation in protein modification studies, and is usually explained by differences in accessibility of the functional groups to the reagents (Cohen, 1968). Altered accessibility of the site of proteolysis could also explain the observed difference in effect of the two proteolytic enzymes trypsin and carboxypeptidase $\mathrm{A}$ in the presence and absence of urea.

Cholera is the prototype for the acute bacterial diarrhoeal diseases named enterotoxic enteropathies (Craig, I972). The techniques described here, which require only small quantities of toxin, may be useful for comparative studies between cholera toxin and other bacterial enterotoxins. Toxoids for immunoprophylaxis against these diseases are urgently required (Feeley, 1974). A formalinized cholera toxoid was tested but was unsuitable due to reversion to toxicity (Northrup \& Chisari, 1972), and glutaraldehyde treatment reduced antigenicity as well as toxicity (Rappaport et al. 1974). The present study has indicated that selective chemical treatments of cholera toxin supported by sensitive methods of detecting the biological results of such treatments might be useful in the search for efficacious toxoid preparations.

We are grateful to Ms Christina Norrman and Ms Gun Wallerström for skilful technical assistance, to Dr C. Miller, Bethesda, for providing the purified cholera toxin and to Dr L. Svennerholm, Göteborg, for generous gifts of pure $\mathrm{G}_{\mathrm{M1}}$ ganglioside. The work was supported by grants from the Swedish Medical Research Council (project no. I6X-3383), the W.H.O., the Medical Faculty at the University of Göteborg, and the Ellen, Walter and Lennart Hesselman Foundation.

\section{REFERENCES}

Cohen, J. A., Oosterbaan, R. A. \& Berends, F. (1967). Analysis of O-phosphorylserine. Methods in Enzymology I1, 686-702.

CoHen, L. A. (1968). Group-specific reagents in protein chemistry. Annual Review of Biochemistry 37, $695-726$.

Craig, J. P. (1965). A permeability factor (toxin) found in cholera stools and culture filtrates and its neutralization by convalescent cholera sera. Nature, London 207, 6I4-6I6.

Craig, J. P. (1972). The enteropathies. In Microbial Pathogenicity in Man and Animals, pp. I 29-1 52. Edited by H. Smith and J. H. Pearce. Cambridge: Cambridge University Press.

Cuatrecasas, P. (1973a). Interaction of Vibrio cholerae enterotoxin with cell membranes. Biochemistry $\mathbf{1 2}$, 3547-3558.

Cuatrecasas, P. (1973b). Gangliosides and membrane receptors for cholera toxin. Biochemistry 12, 35583566.

Cuatrecasas, P., Parikh, I. \& Hollenberg, M. D. (1973). Affinity chromatography and structural analysis of Vibrio cholerae enterotoxin-ganglioside agarose and the biological effects of ganglioside containing soluble polymers. Biochemistry 12, 4253-4263.

FeEley, J. C. (1974). Antitoxic immunity in cholera. In Cholera, pp. 307-314. Edited by D. Barua and W. Burrows. Philadelphia: W. B. Saunders.

Field, M., Fromm, D., Al-Awqati, Q. \& Greenough, W. B., III (I972). Effect of cholera enterotoxin on ion transport across isolated ileal mucosa. Journal of Clinical Investigation 51, 796-804.

FinkelsteIn, R. A. (1973). Cholera. CRC Critical Reviews in Microbiology 2, 553-623. 
Finkelstein, R. A., Fujita, K. \& Lo Spalluto, J. J. (I97I). Procholeragenoid: an aggregated intermediate in the formation of choleragenoid. Journal of Immunology 107, 1043-I05I.

Finkelstein, R. A. \& Lo Spalluto, J. J. (1970). Production of highly purified choleragen and choleragenoid. Journal of Infectious Diseases 121, pp. 63-72.

GURD, F. (1967). Carboxymethylation. Methods in Enzymology 11, 532-541.

vaN Heyningen, S. (1974). Cholera toxin: interaction of subunits with ganglioside $\mathrm{G}_{\mathrm{M}_{1}}$. Science, New York I83, 656-657.

HIRs, C. H. W. (1967). Reduction and S-carboxymethylation of proteins. Methods in Enzymology I1, I99-204.

Hoare, D. G. \& Koshland, D. E., Jun. (I966). A procedure for the selective modification of carboxyl groups in proteins. Journal of the American Chemical Society 88, 2057-2058.

Holmgren, J. (1973). Comparison of the tissue receptors for Vibrio cholerae and Escherichia coli enterotoxins by means of gangliosides and natural cholera toxoid. Infection and Immunity 8, 85I-859.

Holmgren, J., LindHOLM, L. \& LönNROTH, I. (1974). Interaction of cholera toxin and toxin derivatives with lymphocytes. I. Binding properties and interference with lectin-induced cellular stimulation. Journal of Experimental Medicine 139, 80 I-8I9.

Holmgren, J. \& LönNROTH, I. (I975). Oligomeric structure of cholera toxin: characteristics of the $\mathbf{H}$ and L subunits. Journal of General Microbiology 86, 49-65.

Holmgren, J., Lönnroth, I., MÅnsson, J. E. \& Svennerholm, L. (1975). Interaction of cholera toxin and membrane $\mathrm{G}_{\mathrm{M}_{1}}$ ganglioside of small intestine. Proceedings of the National Academy of Sciences of the United States of America 72, 2520-2524.

Holmgren, J., LönnRoth, I. \& SVennerholm, L. (1973). Tissue receptor for cholera exotoxin: postulated structure from studies with $\mathrm{G}_{\mathrm{M} 1}$ ganglioside and related glycolipids. Infection and Immunity 8, $208-214$.

Holmgren, J. \& Svennerholm, A.-M. (1973). Enzyme-linked immunosorbent assays for cholera serology. Infection and Immunity 7, 759-763.

Horinishi, H., Hachimori, Y., Kurihara, K. \& Shibata, K. (i964). States of amino acid residues in proteins. III. Histidine residues in insulin, lysozyme, albumin and proteinases as determined with a new reagent diazo-I H-tetrazole. Biochimica et biophysica acta 86, 477-489.

HoRTON, H. R. \& KoSHLAND, D. E., JUN. (1967). Reactions with reactive alkyl halides. Methods in Enzymology II, 556-565.

HuANG, W. Y. \& TANG, J. (1972). Modification of an arginyl residue in pepsin by 2,3-butandione. Journal of Biological Chemistry 247, 2704-27I0.

Hughes, W. L., Jun., Saroff, H. A. \& Carney, A. L. (1949). Preparation and properties of serum and plasma proteins. XXII. A crystallizable guanidated derivate of human serum albumin. Journal of the American Chemical Society 7r, 2476-2480.

Hunter, W. M. \& Greenwgod, F. C. (1962). Preparation of iodine-I 3I labelled human growth hormone of high specific activity. Nature, London 194, 495-496.

Ishikura, H., Takahashi, K., Titani, K. \& Minakami, S. (I959). The structure of cytochrome C. V. Diazocoupling and iodination of cytochrome C. Journal of Biochemistry 46, 719-724.

King, C. A. \& VAN Heyningen, W. E. (1973). Deactivation of cholera toxin by a sialidase-resistant monosialosylganglioside. Journal of Infectious Diseases 127, 639-647.

KLotz, I. M. (1967). Succinylation. Methods in Enzymology Ir, 576-580.

Lo Spalluto, J. J. \& Finkelstein, R. A. (I972). Chemical and physical properties of cholera exo-enterotoxin (choleragen) and its spontaneously formed toxoid (choleragenoid). Biochimica et biophysica acta 257, I 58-I 66.

LÖNNROTH, I. \& Holmgren, J. (1973). Subunit structure of cholera toxin. Journal of General Microbiology 76, 417-427.

LönNRoth, I. \& Holmgren, J. (1974). Chemical modification of cholera toxin for characterization of antigenic, receptor-binding and toxics sites. FEBS Letters 44, 282-285.

Northrup, R. S. \& Chisari, F. V. (1972). Response of monkeys to immunization with cholera toxoid, toxin, and vaccine: reversion of cholera toxoid. Journal of Infectious Diseases 125, 47I-479.

OKuYama, T. \& SATAKE, K. (1960). On the preparation and properties of 2,4,6-trinitrophenyl-amino acids and -peptides. Journal of Biochemistry 47, 454-467.

Pierce, N. F., Greenough, W. B., III \& Carpenter, C. C. (197I). Vibrio cholerae enterotoxin and its mode of action. Bacteriological Reviews 35, I-I3.

RamachandRan, L. K. \& Witkop, B. (1967). N-bromosuccinimide cleavage of peptides. Methods in Enzymology II, 283-299.

Rappaport, R. S., Boude, G., McCann, T., Rubin, B. A. \& Tint, H. (1974). Development of a purified cholera toxoid. II. Preparation of a stable, antigenic toxoid by reaction of purified toxin with glutaraldehyde. Infection and Immunity 9, 304-3I 7.

Riordan, J. F., Sokolovsky, M. \& Vallee, B. L. (1966). Tetranitromethane. A reagent for the nitration of tyrosine and tyrosyl residues of proteins. Journal of the American Chemical Society 88, 4104-4105.

Riordan, J. F. \& Vallee, B. L. (I967a). Reactions with N-ethylmaleimide and p-mercuribenzoate. Methods in Enzymology II, 54I-548.

Riordan, J. F. \& VALleE, B. L. (1967b). Acetylation. Methods in Enzymology r1, 565-570. 
SChAFER, D. E., LuST, W. D., SirCar, B. \& GoldberG, N. D. (1970). Elevated concentration of adenosine3,5-cyclic monophosphate in intestinal mucosa after treatment with cholera toxin. Proceedings of the National Academy of Sciences of the United States of America 67, 851-856.

Sharp, G. W. G. \& Hynie, S. (1970). Stimulation of intestinal adenylcyclase by cholera toxin. Nature, London 229, 266-269.

Svennerholm, L. (1972). Gangliosides, isolation. In Methods in Carbohydrate Chemistry, vol. 6, pp. 464474. Edited by R. L. Whistler and J. N. BeMiller. New York: Academic Press.

TAKAHASHI, K. (1968). The reaction of phenylglyoxal with arginine residues in proteins. Journal of Biological Chemistry 243, 6I 7I-6I 79.

Toi, K., Bynum, E., Norris, E. \& Itano, H. A. (1967). Studies on the chemical modification of arginine. I. The reaction of 1,2 -cyclohexandione with arginine and arginyl residues of proteins. Journal of Biological Chemistry 242, 1036-1043.

WoLD, F. (1967). Bifunctional reagents. Methods in Enzymology Ir, 61 7-640.

Yamada, S. \& ItANo, H. A. (1966). Phenanthrenequinone as an analytical reagent for arginine and other monosubstituted guanidines. Biochimica et biophysica acta 130, 538-540. 